\title{
Prevalence and Characterization of Bacillus cereus in Raw Poultry Meat Sold at Retail Meat Outlets of Bikaner
}

\author{
Paramjeet Kaur*, Rakesh Rao, Sunil Meherchandani Rajani Joshi, \\ Manohar Sain and Pankaj Mangal \\ Department of Veterinary Public Health, College of Veterinary and Animal Science, \\ RAJUVAS, Bikaner- 334001, Rajasthan, India \\ *Corresponding author
}

\begin{tabular}{|c|c|}
\hline & A B S T R A C T \\
\hline $\begin{array}{l}\text { Poultry, Bacillus } \\
\text { cereus, Polymerase } \\
\text { chain reaction, Food } \\
\text { poisoning }\end{array}$ & \multirow{3}{*}{$\begin{array}{l}\text { The present study was carried out to isolate Bacillus cereus from meat collected from } \\
\text { Bikaner. In this study } 50 \text { raw poultry meat samples were collected from various retail meat } \\
\text { outlets of Bikaner city. Out of } 50 \text { raw poultry meat samples, } 14 \text { ( } 28 \% \text { ) samples were found } \\
\text { positive for Bacillus cereus by culture and biochemical tests. The isolates showing positive } \\
\text { reaction for the Catalase test, Voges Proskauer's test, Arginine test, Nitrate reduction test, } \\
\text { Citrate utilization test and sugar tests like Glucose, Sucrose, Arabinose and Trehalose } \\
\text { while negative with ONPG test, Mannitol and Malonate test were confirmed as Bacillus } \\
\text { cereus. Phenotypically identified B. cereus isolates were further analysed by polymerase } \\
\text { chain reaction technique. The } 14 \text { isolates were subjected to PCR. Out of } 14 \text {, } 12(85.71 \%) \\
\text { isolates possessed gyrB gene and were confirmed as B. cereus. Hence it was concluded } \\
\text { that the occurrence of B. Cereus in foods especially in raw meat as a meat contaminant and } \\
\text { causes food poisoining which is a serious public health concern and need to be addressed. }\end{array}$} \\
\hline Article Info & \\
\hline $\begin{array}{l}\text { Accepted: } \\
20 \text { August } 2020 \\
\text { Available Online: } \\
\text { 10 September } 2020\end{array}$ & \\
\hline
\end{tabular}

\section{Introduction}

Food poisoning diseases are continuing problem of high magnitude in both, developed and developing countries. The pathogens transmitted through food contribute 30 percent to globally emerging infections (Carlin et al., 2009). In all over the world, morbidity and mortality are attributed to gastroenteritis, due to food borne diseases which pose a serious threat to public health. Food borne pathogens are leading cause of illness and death in developing countries costing billions of dollars in medical care
(Fratamico, 2005) and it is well documented that contamination of food with pathogens is a major public health concern worldwide (Mead,1994). Microorganisms present in the meat may be harmful for human that cause spoilage and may be used as indicator organisms (Bhandre et al., 2007).

Amongst the organisms responsible for causing foodborne diseases, Bacillus cereus has emerged as major foodborne pathogen during the last few decades and is often present in a variety of foods, such as starchy foods (rice), animal origin foods (meat, milk 
and dairy products) and others like vegetables, spices, cake desserts etc. In India, occurrence of $B$. cereus has been reported from foods like milk (Garg et al., 1977; Chopra et al., 1980), meat (Bacchil and Jaiswal, 1988) and various other foods such as, fried rice, cereals and egg etc (Meena et al., 2000).

Bacillus cereus is a spore-forming, aerobic to facultative anaerobic, Gram-positive, motile rod that can be isolated from a wide variety of different sites (Kotiranta et al., 2000). It grows over a wide temperature range 10 to $48^{\circ} \mathrm{C}$ with an optimum range of 28 to $35^{\circ} \mathrm{C}$. It also grows over a wide $\mathrm{pH}$ range from 4.9 . 9.3 and approximately $7.5 \%$ concentration of sodium chloride. Microscopically it may be seen in chains and macroscopically the colonies have a dull or frosted glass appearance on a nutrient agar plate (Lattuada \& McClain, 1998).

Bacillus cereus is an ubiquitous organism encountered in many types of food. According to Food and Drug Administration of the United States of America, food poisonings caused by Bacillus cereus are presented in two different clinical syndromes i.e. diarrheal and emetic syndrome.

The primary diagnosis of Bacillus cereus food poisoning is done by isolation of the pathogen from specimens like faeces, vomitus and foods etc. Though Bacilli have been presumptively identified and characterized based on their morphology and biochemical profile yet use of these conventional as well as 16S DNA sequence analysis tests may be insufficient to differentiate Bacillus cereus from other members of Bacillus cereus group as these members share a quite significant degree of genetic and phenotypic similarities (Rhodehamel and Harmon, 2001). The organisms isolated from meat and meat products in different regions might have enough diversity at genetic level and can be classified at genetic level by using molecular techniques like polymerase chain reaction. The species of the Bacillus cereus group have a high level of DNA homology (Seki et al., 1978), but a specific sequence within $g y r B$ gene can distinguish Bacillus cereus from the other members of the group (Yamada et al., 1999). Therefore, the main objective of this study is to isolate Bacillus cereus by culture and biochemical tests and confirm by detection of specific gene $g y r B$ from raw poultry meat samples.

\section{Materials and Methods}

The present study was conducted at the Department of Veterinary Public Health, College of Veterinary and Animal Science, Rajasthan University of Veterinary and Animal Sciences, Bikaner, India

A total of 50 raw poultry meat samples were collected for the present study from retail meat outlets of Bikaner city. About 10-20 grams of raw meat samples were collected in sterilized test tubes and immediately brought to the laboratory under cold conditions. The samples were processed within 4-6 hours of collection. For isolation of this organisms all the samples were enriched in brain heart infusion and then processed for staining.

Each raw poultry sample was streaked on Nutrient agar, and plates in primary, secondary, and tertiary fashion in order to obtain isolated colonies of bacteria. These petri plates were incubated for $24 \mathrm{hr}$ at $37^{\circ} \mathrm{C}$. After $24 \mathrm{hr}$ incubation these isolated colonies were culture on Mannitol egg yolk Polymyxin (MYP) agar plates for isolation of Bacillus cereus and incubated for 24 hours at $32^{\circ} \mathrm{C}$. The growth was examined for the colonial morphology and pigmentation and different types of colonies were sub-cultured on separate nutrient agar plates in order to 
obtain a pure culture. Bacillus cereus isolates were gram positive, catalase positive, Mannitol negative and producing rough pinkish colonies with zone of precipitation around the colonies on Mannitol egg yolk Polymyxin agar

The confirmation of the Bacillus cereus isolates as were done by using Gram's staining, and a set of 12 biochemical tests provided in HiBacillus ${ }^{\mathrm{TM}}$ identification kits for Bacillus cereus were used.

The genotypic characterization was carried out by PCR which was used for detection of species specific gyrB gene by following methodologies described by Park et al., (2007). The optimized PCR was carried out in a final reaction volume of $25 \mu \mathrm{l}$ and the cycling conditions consisted of an initial denaturation at $94^{\circ} \mathrm{C}$ for 5 minutes, 35 cycles of amplification with denaturation at $94^{\circ} \mathrm{C}$ for 60 seconds, annealing at $63^{\circ} \mathrm{C}$ for 30 seconds, an extension at $72^{\circ} \mathrm{C}$ for 45 seconds and final extension of the incompletely synthesized DNA at $72^{\circ} \mathrm{C}$ for 7 minutes. The primers used for detection of $g y r B$ gene for characterization of $B$. cereus isolates were synthesized by Xcelris Lab Ltd. Ahmedabad, Gujrat, India The confirmation and resolution of the PCR product was done by agarose gel electrophoresis using $1 \%$ agarose gel.

\section{Results and Discussion}

In the present study out of 50 raw poultry meat samples processed 14(28\%) samples were found positive for Bacillus cereus (Figure-1). Scheimann (1978) reported that $16.96 \%$ meat samples to be positive for Bacillus cereus which is lower than present study. Sooltan (1987) observed 6.9\% samples and Konuma (1988) found $16.3 \%$ samples to be positive for Bacillus cereus which is also lower than present investigation. Bedi et al., (2004) isolated $56.3 \%$ Bacillus cereus from the raw meat samples collected from the areas in and around Ludhiana, Punjab which is just double to our present study, while Smith et al., (2004) reported $45 \%$ poultry samples to be positive for Bacillus cereus which is higher than present study. Tewari et al., (2015) isolated $27.8 \%$ raw poultry samples positive in different parts of northern India which is almost similar to that of present investigation. Abd-El-Tawab et al., (2015) reported 38.33\% of Bacillus cereus, which is also higher than present study. Bashir et al., (2017) recorded $28 \%$ Bacillus cereus in poultry meat samples collected from the cities of Jammu which is in complete agreement to our study. Acun et al., (2018) isolated 12\%Bacillus cereus which is lower whereas, Osman et al., (2018) reported $50 \%$ Bacillus cereus in poultry meat samples which is higher than present investigation. Gdoura-Ben Amor et al., (2018) observed lower prevalence of Bacillus cereus $(9.4 \%)$ while Jawad et al., (2018) reported much higher prevalence $(50 \%)$ than present investigation. Solanki et al., (2019) also observed $20 \%$ prevalence in the poultry samples collected from Gujarat; whereas, Zaki and Hadad (2019) isolated 8.6\% Bacillus cereus which are lower than that reported from the present investigation.

In the present study all the isolates that were Gram's positive, catalase positive and pink colonies on Mannitol egg yolk polymyxin agar (MYPagar) were considered as Bacillus cereus. All Bacillus cereus strains gave opaque zone around the colony on MYP agar. For confirmation of Bacillus cereus HiBacillus ${ }^{\mathrm{TM}}$ identification kits were used. The isolates showing positive reaction for the Catalase test, Voges proskauer's test, Arginine test, Nitrate reduction test, Citrate utilization test and sugar tests like Glucose, Sucrose, Arabinose and Trehalose while negative with ONPG test, Mannitol and Malonate test were confirmed as Bacillus cereus. All the isolates confirmed as Bacillus 
cereus showed $100 \%$ positive reaction with the Citrate utilization test, Nitrate reduction test, Arabinose and Trehalose sugar test. Arginine and Sucrose showed $92.8 \%$ positive reaction while Catalase and Glucose test showed $85.71 \%$ positive reaction. Voges Proskauer's test showed $78.57 \%$ positive reaction. Mannitol test showed $100 \%$ negative reaction while ONPG and Malonate test showed $85.71 \%$ negative reaction (Figure13). Variability in the results might have occurred due to presence of different types of strains of Bacillus cereus. The detailed results of various biochemical tests performed for Bacillus cereus are shown in table 1.

Table.1 Results of biochemical tests for Bacillus cereus using HiBacillus ${ }^{\mathrm{TM}}$ identification kits

\begin{tabular}{|c|c|c|c|c|c|}
\hline \multirow{2}{*}{$\begin{array}{c}\text { S. } \\
\text { No. }\end{array}$} & \multirow{2}{*}{ TEST } & \multicolumn{2}{|c|}{ POSITIVE } & \multicolumn{2}{c|}{ NEGATIVE } \\
\cline { 3 - 6 } & & Number & $\%$ & Number & $\%$ \\
\hline $\mathbf{1 .}$ & Malonate & $02 / 14$ & $14.29 \%$ & $12 / 14$ & $85.71 \%$ \\
\hline $\mathbf{2 .}$ & Voges proskauer's & $11 / 14$ & $78.57 \%$ & $03 / 14$ & $21.43 \%$ \\
\hline $\mathbf{3 .}$ & Citrate utilisation & $14 / 14$ & $100 \%$ & $0 / 14$ & $0 \%$ \\
\hline $\mathbf{4 .}$ & ONPG & $02 / 14$ & $14.29 \%$ & $12 / 14$ & $85.71 \%$ \\
\hline $\mathbf{5 .}$ & Nitrate reduction & $14 / 14$ & $100.00 \%$ & - & - \\
\hline $\mathbf{6 .}$ & Catalase & $12 / 14$ & $85.71 \%$ & $02 / 14$ & $14.29 \%$ \\
\hline $\mathbf{7 .}$ & Arginine & $13 / 14$ & $92.8 \%$ & $01 / 14$ & $7.2 \%$ \\
\hline $\mathbf{8 .}$ & Sucrose & $13 / 14$ & $92.8 \%$ & $01 / 14$ & $7.2 \%$ \\
\hline $\mathbf{9 .}$ & Mannitol & $0 / 14$ & $0 \%$ & $14 / 14$ & $100 \%$ \\
\hline $\mathbf{1 0}$ & Glucose & $12 / 14$ & $85.71 \%$ & $02 / 14$ & $14.29 \%$ \\
\hline $\mathbf{1 1}$ & Arabinose & $14 / 14$ & $100 \%$ & $0 / 14$ & $0 \%$ \\
\hline $\mathbf{1 2}$ & Trehalose & $14 / 14$ & $100 \%$ & $0 / 14$ & $0 \%$ \\
\hline
\end{tabular}

Fig.1 Isolation of Bacillus cereus on Mannitol egg yolk Polymyxin agar from Poultry meat Samples

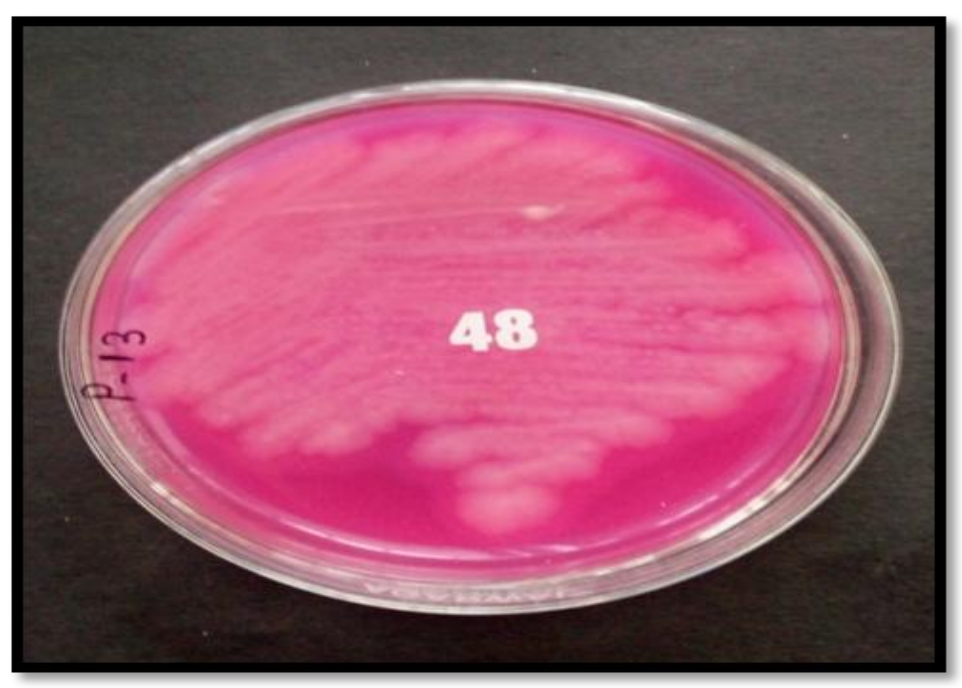


Fig.2 Results of biochemical tests for Bacillus cereus obtained from HiBacillus ${ }^{\mathrm{TM}}$ commercial kits

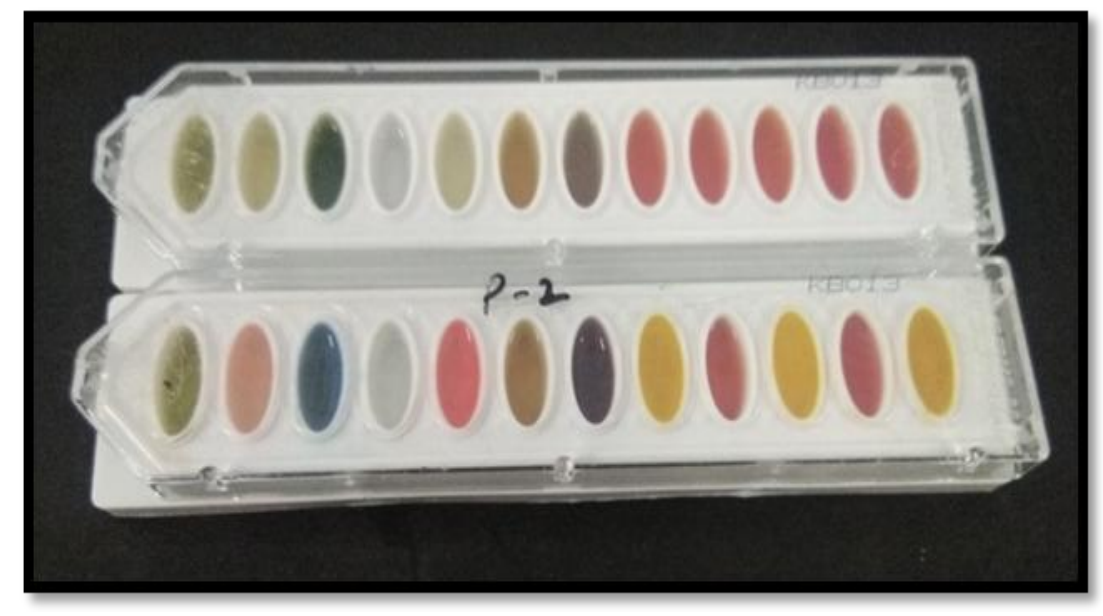

Fig.3 Polymerase Chain Reaction based on species specific primer

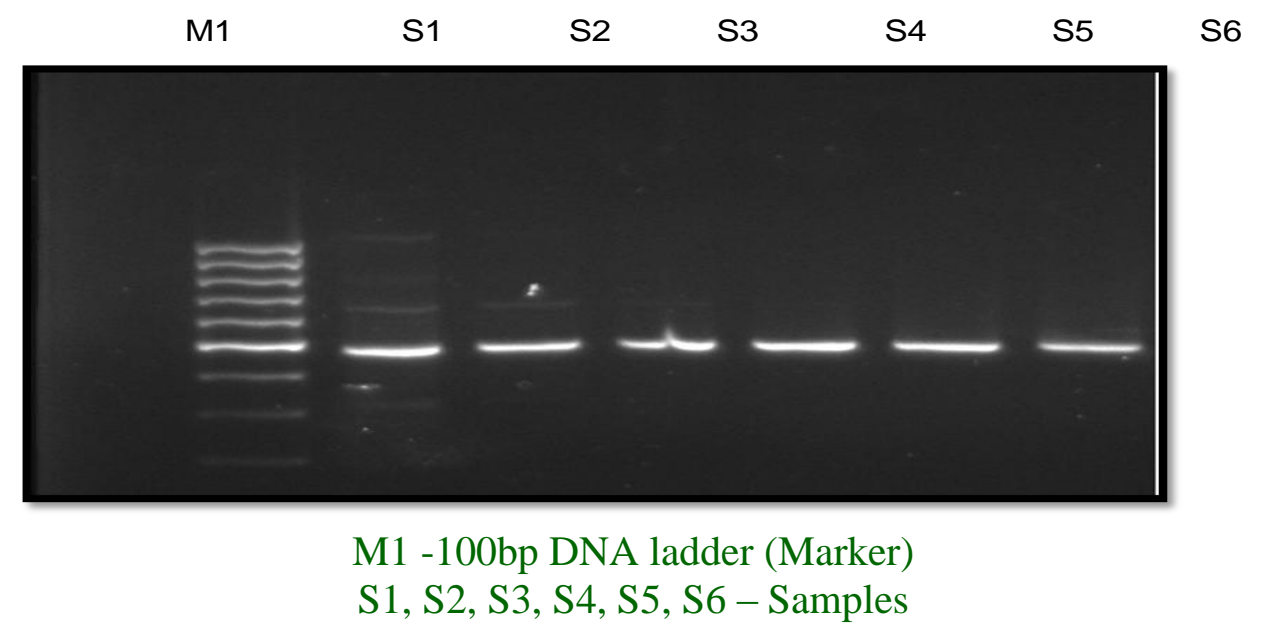

All the Bacillus cereus isolates were screened for the presence or absence of species specific gyrB gene using PCR technique. The PCR was standardized for the detection of gene, gyrB, following the methodology as described by Mudasir Bashir et al., (2017) and Park et al., (2007) with suitable modifications.

In the present study out of 50 raw poultry meat samples, 14 samples were found positive for Bacillus cereus (28\%) by culture and HiBacillus ${ }^{\mathrm{TM}}$ identification kits. A total of 12 samples $(85.71 \%)$, out of 14 were found positive by Polymerase Chain Reaction through amplification of Bacillus cereus specific 475bp amplicon (sequence within gyrB gene). A specific sequence within gyrB gene can distinguish Bacillus cereus from the other members of the group (Yamada et al., 1999). Almost similar results reported by LaDuc et al., (2004) and Bashir et al., (2017) that characterized Bacillus cereus group phylogenetically and found $84.6 \%$ isolates positive by PCR. Rather et al., (2012) and Tewari et al., (2015) confirmed $98.3 \%$ and $100 \%$ isolates targeting species specific $g y r B$ 
gene by using PCR which is higher than present investigation.

\section{Acknowledgement}

We extend our sincere gratitude to dean, College of Veterinary and Animal Science, Rajasthan University of Veterinary and Animal Sciences, Bikaner-334001 for providing necessary facilities and funds to carry out this work.

\section{References}

Abd El Tawab, A. A.; El-Hofy, F. I.; Khater, D. F. and AL-Baaly, Y. M. (2015). Molecular studies on toxigenic strains of Bacillus cereus isolated from some meat products. Benha Veterinary Medical Journal. 29(1): 129-133.

Acun, A.; Sancar, B. C. and Ozpınar, H. (2018). Examination of Food Samples Taken From Catering Enterprises in İstanbul in Terms of Bacillus cereus, Salmonella spp. and Escherichia coli O157: H7. Asian Journal of Agriculture and Food Sciences . 6(01): 2321-1571.

Bashir, M.; Malik, M. A.; Javaid, M.; Badroo, G. A.; Bhat, M. and Singh, M. (2017). Prevalence and characterization of Bacillus cereus in meat and meat products in and around Jammu region of Jammu and Kashmir, India. International Journal of Current Microbiology and Applied Sciences. 6(12): 1094-1106.

Bedi, S. K.; Sharma, C. S.; Gill, J. P. S.; Aulakh, R. S. and Sharma, J.K. (2004). Bacillus cereus in meat and meat products: isolation, enumeration and enterotoxigenicity. J. Vet. Public Health. 2: 7-10.

Bhandare, S. G.; Sherikarv, A. T.; Paturkar, A. M.; Waskar, V. S. and Zende, R. J. (2007). A comparison of microbial contamination of sheep/goat carcasses in a modern Indian abattoir and traditional meat shops. Food Contr. 18: 854-868.

Carlin, F.; Brillard, J.; Broussolle, V.; Clavel,
T.; Duport, C.; Jobin, M.; Guinebretiere, M.H.; Auger, S.; Sorokine, A. and Nguyen-The, C. (2009). Adaptation of Bacillus cereus, an ubiquotious worldwide distributed foodborne pathogen, to a changing environment. Food Res. Int. 30: 30-32.

Chopra, P.; Singh, A.; Kalra, M. S. and Singh, A. (1980). Occurrence of Bacillus cereus in milk and milk products. Indian Journal of Dairy Science. 33(2): 248-252.

Ehling-Schulz, M.; Vukov, N.; Schulz, A.; Shaheen, R.; Andersson, and M.Märtlbauer, E. (2005). Identification and partial characterization of the non ribosomal peptide synthetase gene responsible for cereulide production in emetic Bacillus cereus. Appl.Environ.Microbiol. 71: 105-113.

Fratamico, P. M.; Bhunia, A. K. and Smith, J. L. (2005). Foodborne pathogens: microbiology and molecular biology. Horizon Scientific Press.

Garg, D. N.; Bhargwa, D. N. and Narayan, K. G. (1977). Pathogenic bacterial flora of raw market milk. Indian Journal of Dairy Science. 30(1): 36-39.

Gdoura-Ben Amor, M.; Siala, M.; Zayani, M.; Grosset, N.; Smaoui, S.; Messadi-Akrout, F. and Gdoura, R. (2018). Isolation, identification, prevalence, and genetic diversity of Bacillus cereus group bacteria from different foodstuffs in Tunisia. Frontiers in microbiology. 9: 447.

Granum, P. E. (1994) Bacillus cereus and its toxins. Journal of Bacteriology Symposium Supplement..76:61-66.

Granum, P. E. and Lund, T. (1997)."Bacillus cereus and its food poisoning toxins." FEMS Microbiology Letters. 157: 223228.

Jawad, N.; Ahemd, A. and Abdullah, A. (2018). Determination of haemolytic and non haemolytic genes profiles of Bacillus cereus strains isolated from food samples by polymerase chain reaction (pcr) technique. In AIP Conference Proceedings. 1940(1): 020075). AIP Publishing. 
Konuma, H.; Shinagawa, K.; Tokumaru, M.; Onoue, Y.; Konno, S.; Fujino, N.; Shigehisa, T.; Kurata, H.; Kuwabara, Y.; Lopes, C. A. M. (1988). Occurrence of Bacillus cereus in meat products, raw meat and meat product additives. $J$ Food Prot. 51(4): 324-326.

La Duc, M. T.; Satoni, M.; Agata, N. and Venkateswaran, K. (2004). GyrB as a phylogenetic discriminator for members of the Bacillus anthracis-cereusthuringensis group. J. Microbiol. Methods. 56(3): 383-394.

Osman, K. M.; Kappell, A. D.; Orabi, A.; AlMaary, K. S.; Mubarak, A. S.; Dawoud, T. M. and Hristova, K. R. (2018). Poultry and beef meat as potential seedbeds for antimicrobial resistant enterotoxigenic Bacillus species: a materializing epidemiological and potential severe health hazard. Scientific reports.8(1):11600.

Park, S.; Kim, H.; Kim, J.; Kim, T. and Kim, H. (2007). Simultaneous detection and identification of Bacillus cereus group bacteria using multiplex PCR. $J$. Microbiol Biotechnol. 17(7): 1177-1182.

Rather, M. A.; Aulakh, R. S.; Gill, J. P. S. and Ghatak, S. (2012). Enterotoxin gene profile and antibiogram of Bacillus cereus strains isolated from raw meats and meat products. J. Food Saf. 32: 22-28.

Rhodehamel, E. J. and Harmon, S. M. (2001). Bacillus cereus in Bacteriological Rather, M. A.; Aulakh, R. S.; Gill, J. P. S. and Ghatak, S. (2012). Enterotoxin gene profile and antibiogram of Bacillus cereus strains isolated from raw meats and meat products. J. Food Saf. 32: 22-28.

Schiemann, D. A. (1978). Occurrence of
Bacillus cereus and the bacteriological quality of Chinese "take-out" foods. Journal of Food Protection. 41(6): 450454.

Smith, D. P.; Berrang, M. E.; Feldner, P. W.; Phillips, R. W. and Meinersmann, R. J. (2004). Detection of Bacillus cereus on selected retail chicken products. Journal of food protection. 67(8): 1770-1773.

Solanki, K. S.; Parmar, B. C.; Brahmbhatt, M. N.; Nayak, J. B. and Begadiya, H. B. (2019). Cultural and Biochemical Characterization of $B$. cereus Isolates and Multidrug Resistant Detection of $B$. cereus Isolates Collected from Various Chicken Shops of Market in and around Anand, Gujarat, India. Int. J. Curr. Microbiol. App. Sci. 8(3): 910-915.

Sooltan, J. R. A.; Mead, G .C. and Norris, A.P. (1987). Incidence and growth potential of Bacillus cereus in poultry meat products. Food Microbiol. 4: 347-351.

Tewari, A.; Singh, S.P. and Singh, R. (2015). Incidence and enterotoxigenic profile of Bacillus cereus in meat and meat products of Uttarakhand, India. J. Food Sci.Technol. 52(3): 1796- 1801.

Yamada, S.; Ohashi, E.; Agata, N. and Venkateshwaran, K. (1999). Cloning and nucleotide sequence analysis of gyrB of $B$. cereus, $B$. thuringiensis, B. mycoides and $B$. anthracis and their application to the detection of B. cereus in rice. Applied Environmental Microbiology. 65: 14831490.

Zaki, R. S. and Hadad, G. A. (2019). Rate of Salmonellae and Bacillus cereus in some Retailed cut-up Chicken and Poultry Meat Products. Journal of Advanced Veterinary Research. 9(2): 76-80.

\section{How to cite this article:}

Paramjeet Kaur, Rakesh Rao, Sunil Meherchandani Rajani Joshi, Manohar Sain and Pankaj Mangal. 2020. Prevalence and Characterization of Bacillus cereus in Raw Poultry Meat Sold at Retail Meat Outlets of Bikaner. Int.J.Curr.Microbiol.App.Sci. 9(09): 3088-3094. doi: https://doi.org/10.20546/ijcmas.2020.909.381 